\title{
Clobazam as an Add-on Therapy of Patients with Drug-resistant Epilepsy: Experience of a Tertiary Epilepsy Center
}

\author{
İlaç Tedavisine Dirençli Epilepsi Hastalarında \\ Klobazam Ekleme Tedavisi: Üçüncü Basamak \\ Epilepsi Merkezi Deneyimi
}

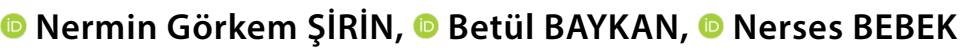 \\ Department of Neurology, Istanbul University İstanbul Faculty of Medicine, İstanbul, Turkey
}

\section{Summary}

Objectives: This retrospective study aimed to overview the efficacy and side effects of clobazam in patients with drug-resistant epilepsy who were followed in a tertiary epilepsy center.

Methods: The patients who had been started clobazam as add-on therapy and have been followed for at least one year were recruited to participate in this study. The clinical, electrophysiologic and imaging features of the patients were reviewed. The side effects and efficacy of clobazam were noted.

Results: Twelve patients with drug-resistant epilepsy who had focal epilepsy with structural etiology in nine, focal epilepsy with unknown etiology in one, combined focal and generalized epilepsy in one and epilepsy with myoclonic absences in one were included in this study. All patients had at least two antiepileptic drugs with moderate to high doses before clobazam therapy. The side effects were sedation, irritability and blurred vision in three patients. Two patients became seizure-free and seven patients had improved remarkably ( $\geq 50 \%$ seizure reduction). Only one patient discontinued the drug because of the side effects.

Conclusion: Our results provide evidence in the efficacy of clobazam as add-on therapy in patients with drug-resistant epilepsy.

Keywords: Antiepileptic drug; clobazam; drug-resistant epilepsy; medically refractory.

\section{Özet}

Amaç: Bu geriye dönük çalışmanın amacı, üçüncü basamak epilepsi merkezinde ilaç tedavisine dirençli epilepsi hastalarında klobazam tedavisinin etkinliğini ve yan etkilerini araştırmaktır.

Gereç ve Yöntem: Klobazamın ek tedavi olarak başlandığı ve tedavi başlandıktan sonra en az bir yıl boyunca takip edilen ilaç tedavisine dirençli hastalar çalışmaya dahil edildi. Hastaların klinik, elektrofizyolojik ve görüntüleme bulguları gözden geçirildi. Klobazam tedavisi sonrası ortaya çıkan yan etkiler ve nöbetler üzerine etkinlik değerlendirildi.

Bulgular: On iki ilaç tedavisine dirençli epilepsi hastası çalışmaya dahil edildi. Hastaların dokuzu yapısal nedene bağlı fokal epilepsi, biri nedeni belirlenemeyen fokal epilepsi, biri kombine fokal ve jeneralize epilepsi ve biri miyoklonik absanslı epilepsi olgusu idi. Hastaların tümü klobazam tedavisi öncesi en az iki antiepileptik ilacı orta-yüksek dozlarda kullanıyordu. Yan etkiler üç hastada görüldü ve sedasyon, iritabilite ve bulanık görme olarak bildirildi. Klobazam tedavisi sonrası hastaların ikisi nöbetsizken, yedisi tedaviden belirgin olarak faydalandı ( $\geq \% 50$ nöbet azalması). Sadece bir hasta yan etkiler nedeniyle tedavi başlangıcından iki ay sonra ilacı bırakmak zorunda kaldı.

Sonuç: Sonuçlarımız, ilaç tedavisine dirençli epilepsi hastalarında ek tedavi olarak klobazam’ın etkin olabileceğini göstermiştir. Anahtar sözcükler: Antiepileptik ilaç; klobazam; ilaca dirençli epilepsi; medikal tedaviye dirençli epilepsi.

(C) 2020 Turkish Epilepsy Society
Submitted (Geliş): 23.01.2020

Accepted (Kabul) : 21.02 .2020

Correspondence (iletişim): Nermin Görkem ŞiRIN, M.D. e-mail (e-posta): gorkemsirin@yahoo.com.tr 


\section{Introduction}

Epilepsy is one of the most common neurological disorders, especially in developing countries. ${ }^{[1]}$ Approximately $30 \%$ percent of patients with epilepsy (PWE) continue to have seizures despite adequate treatment, although several new antiepileptic drugs (AED) emerge in the market in the last two decades. ${ }^{[2]}$ PWE, who are considered as drug-resistant, are targets of new treatment strategies because it is crucial to reduce the frequency of seizures, even reach seizure freedom, to avoid the forthcoming high burden of medical and social risks, such as sudden unexpected death in epilepsy. ${ }^{[3]}$

Clobazam, a 1-5 benzodiazepine, was first used in PWE by Gastaut et al. in $1979^{[4]}$ and has been studied widely in drug-resistant PWE since then. ${ }^{[5-14]}$ It acts through gamma aminobutyric acid (GABA) by enhancing its inhibitory effect. ${ }^{[15]}$ It has good oral bioavailability and high bounding to plasma proteins. ${ }^{[16]}$ The main side effects are dizziness, blurred vision and sedation. ${ }^{[17-20]}$ The latter is suggested to be lesser than 1-4 benzodiazepines like diazepam. ${ }^{[18]}$ Additionally, the tolerance was reported to be lower as compared to clonazepam. Clobazam has been proven to be efficacious in refractory focal or generalized seizures in adults and children as an add-on therapy. ${ }^{[5,9-11,14]}$ Moreover, Federal Drug Administration in the USA was approved its use in the treatment of children with Lennox-Gastaut Syndrome. Clobazam can also be used as monotherapy in non-resistant epilepsies with both focal and generalized seizures. ${ }^{[6,7,21]}$

Clobazam is not already available in Turkey; however, it can be transported from abroad through the Ministry of Health with some special registrations. In this study, we aimed to overview our experience in the efficacy of clobazam as addon therapy in drug-resistant PWE in our tertiary epilepsy center to draw attention to this old under-recognized but useful alternative AED.

\section{Materials and Methods}

\section{Patients}

The files of PWE in our epilepsy outpatient clinic were reviewed and the patients who were started clobazam as add-on therapy and were followed at least one year were recruited to participate in this study.

\section{Data}

The data were collected from the charts of the patients. Age of seizure onset, type of seizures, history of febrile seizures, perinatal hypoxia, meningitis or head trauma were defined. The previous treatment of AEDs before clobazam and last treatment during follow-up were noted. The electrophysiological investigations and MRI studies were overviewed. The epilepsy syndrome was classified according to the latest classification of ILAE. ${ }^{[1]}$ The status of drug-resistant epilepsy was defined as the continuation of seizures despite having at least two appropriate AEDs s a monotherapy or combination. ${ }^{[22]}$

The follow-up period after treatment of clobazam were assessed as seizure freedom or reduction of seizures relative to the mean seizure frequency in one-year before the first dose of clobazam. The side effects were screened in all patients. Blood biochemistry screen and electroencephalogram (EEG) were reviewed in the patients where available. The treatment regimen after starting clobazam could be modified by the physician according to the efficacy or side effects.

The local ethics committee approved this retrospective study (Istanbul University, Istanbul Faculty of Medicine, number 2019/1550).

\section{Results}

Twelve patients were included in this study (mean age $30.3 \pm 9.8$ years, ranging from 14 to 49 years; male: female $=6$ : 6). The mean follow-up of patients was $73.2 \pm 37.1$ months (ranged from 24 to 130 months). The mean age at epilepsy onset was $9.7 \pm 11.3$ years (ranged from 1 week to 45 years). Nine patients were classified as focal epilepsy with structural etiology, one as focal epilepsy with unknown cause, one as epilepsy with myoclonic absences and one as combined focal and generalized epilepsy syndrome (Table 1). All patients had drug-resistant epilepsy, as defined. Active epilepsy duration was $21.9 \pm 11.0$ years (ranged from 3 to 35 years). None of the patients had a remission period except three patients who had two and three years of remission in their early childhood. Two patients had simple and one patient had complex febrile seizures in history. Psychiatric diseases coexisted in two patients. Eight patients had one or two antecedent events like perinatal hypoxia, severe head trauma or febrile seizures. In three patients, there was a family history of epilepsy and/or febrile seizures. The parents of two patients had consanguinity. Ten of twelve patients had mental retardation. Neurological examination revealed abnormal findings in six patients, such as spastic quadriparesis or hemiparesis and ataxia. 


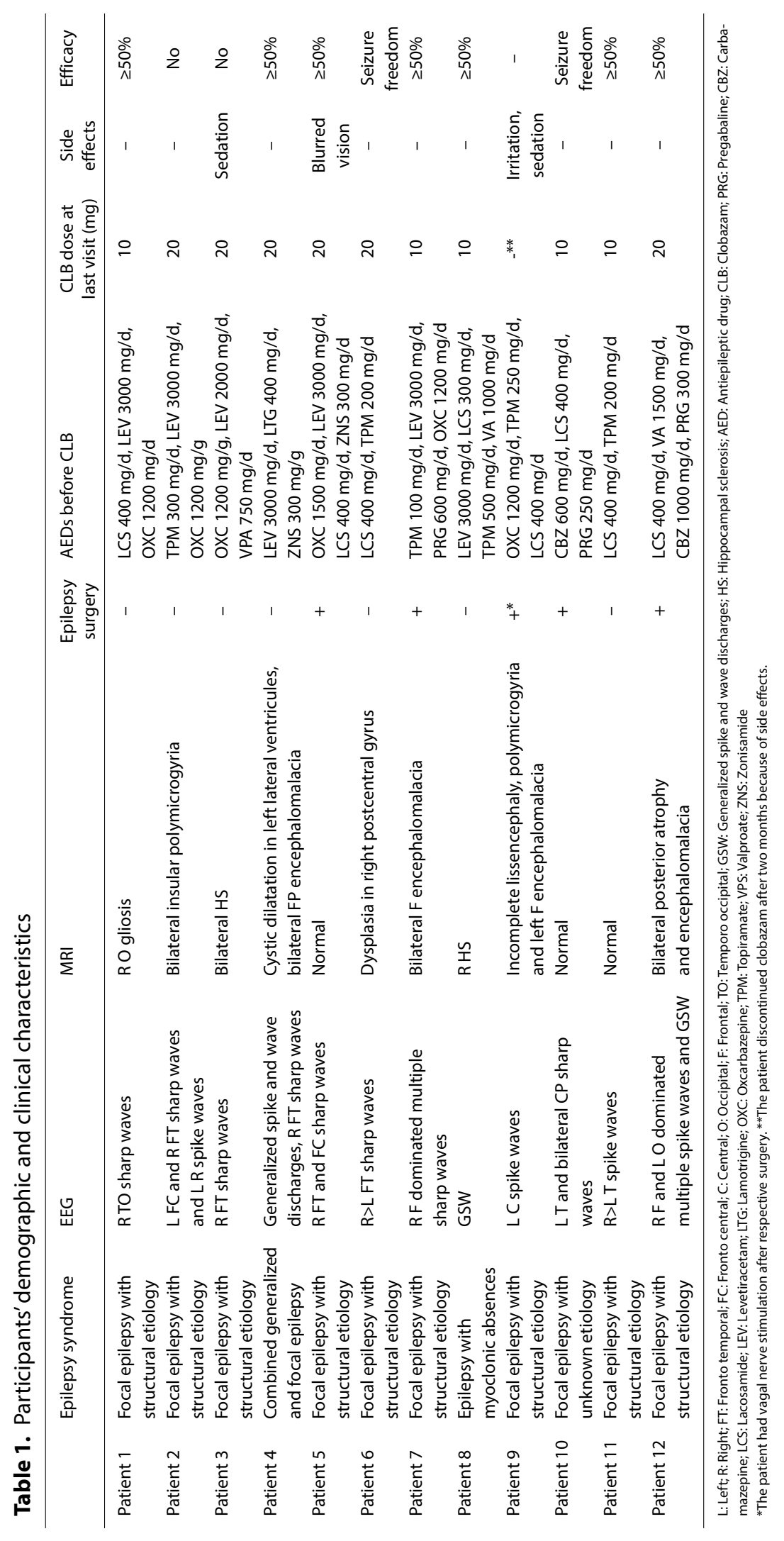




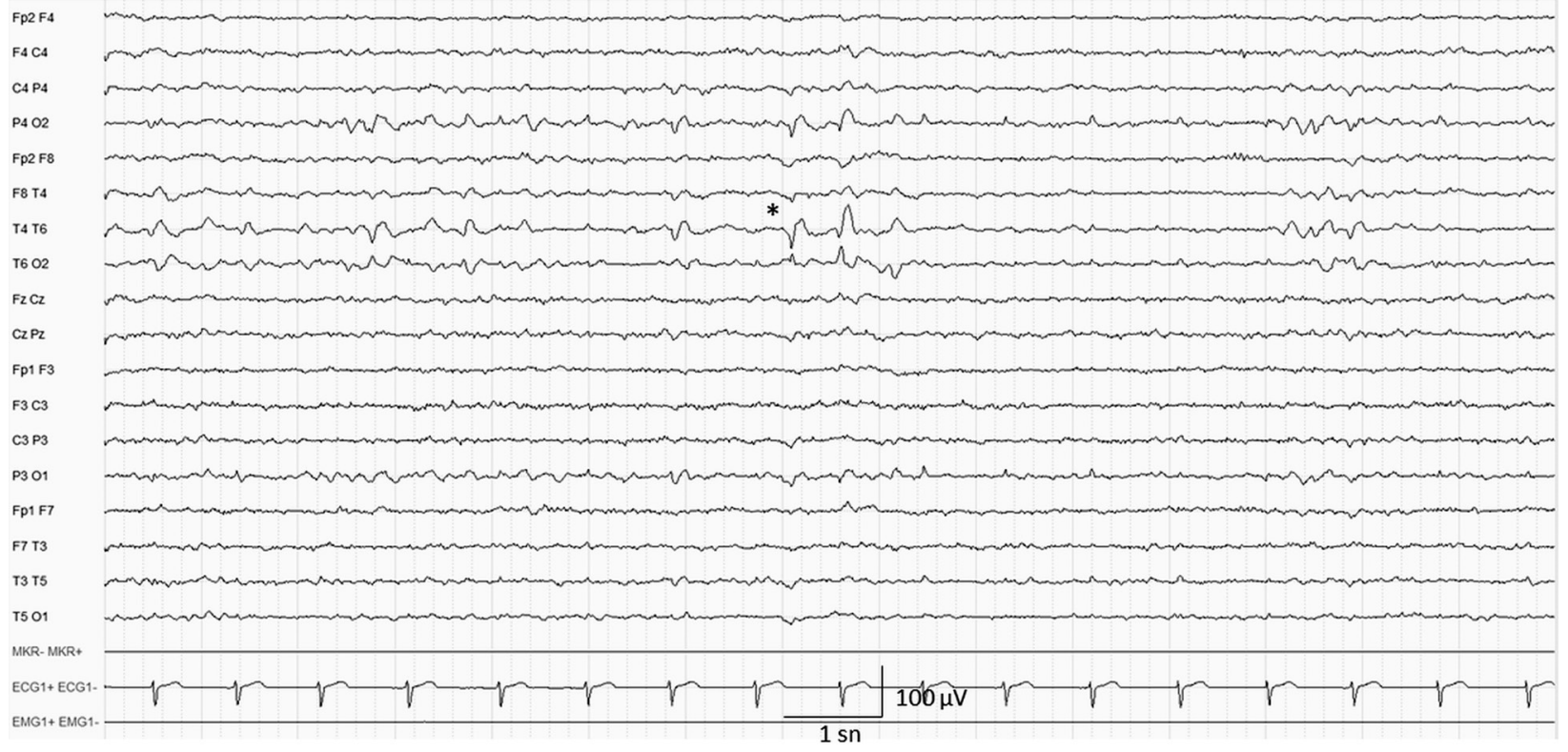

Fig. 1. EEG shows right temporo-occipital sharp waves (asterisk) during drowsiness (Patient 1 in Table 1).

EEG showed several pathological findings, which are summarized in Table 1 (Fig. 1). None of the patients had a normal EEG. All patients had an MRI examination with epilepsy protocol. In three patients, MRI was normal, whereas the rest of the patients had cortical malformations, lesions related to hypoxia or hippocampal sclerosis (Fig. 2). Because all of

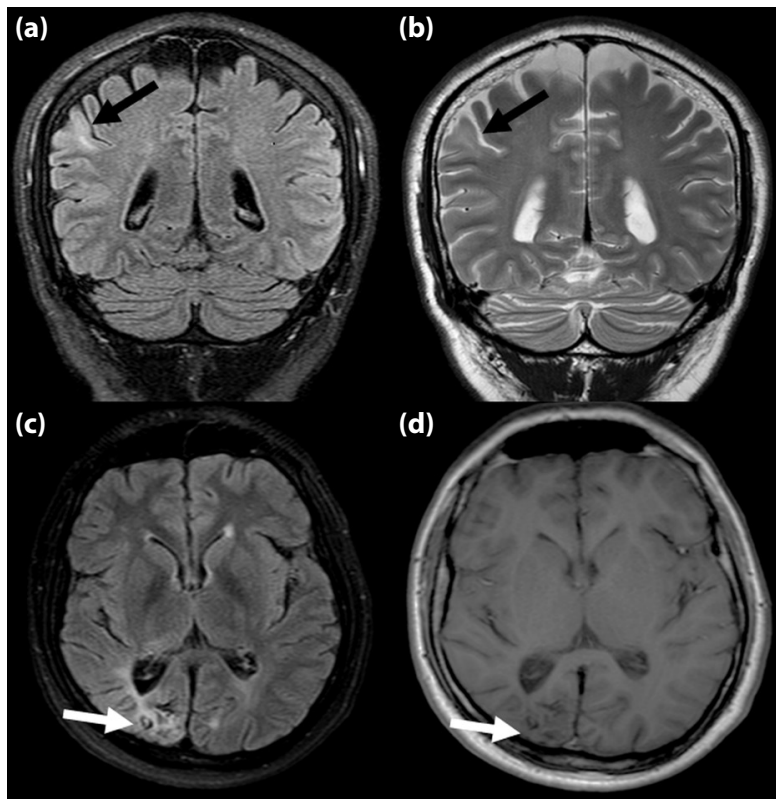

Fig. 2. In (a) and (b), focal cortical dysplasia in right postcentral gyrus marked by black arrow with a hyperintensity in FLAIR and T2 weighted images, respectively (Patient 6 in Table 1). (c) and (d) show right occipital gliosis (white arrow, Patient 1 in Table 1). the patients were diagnosed with drug-resistant epilepsy, all were also evaluated for epilepsy surgery. As a part of this evaluation, all had long-term video-EEG monitoring, and all, but one had PET-CT. One patient had vagal nerve stimulation. Four patients had undergone a resective surgery, who also had intracranial video-EEG monitoring in two. None of these patients who had epilepsy surgery achieved seizure freedom and one of them had vagal nerve stimulation two years after surgery.

All patients had at least two AEDs at the time of the first dose of clobazam (Table 1). Six patients had three, four patients had four and two patients had two different AEDs with moderate to high total doses. The starting dose of clobazam was 5-10 mg/day and clobazam was tapered according to the side effects and seizure frequency. Maximum dose of clobazam was 10-20 mg/day. Side effects were a blurred vision in one, irritability in one, sedation in two patients. Among them, one patient having irritability and sedation together discontinued the drug after two months because of these side effects. All side effects were present within a month. The duration of the use of clobazam was 17.5 \pm 11.9 months, ranged from two to 51 months. Among 11 patients who continued clobazam as add-on therapy, two patients were seizure free and seven patients had a remarkable seizure reduction $(\geq 50 \%)$ at their last visit. In the remaining two patients, seizure frequency showed no change. In all of the nine patients who revealed seizure reduction, except 
one, the doses of other AEDs were tapered and in two, one AED was able to be removed during follow-up. Among the two patients using Valproate, one patient had seizure reduction and the other patient showed no change in seizure frequency.

\section{Discussion}

Our results showed that clobazam might be efficacious as an add-on therapy in drug-resistant PWE. In our cohort, nine patients improved after clobazam therapy (75\%), consisting of two with seizure freedom and seven with $\geq 50 \%$ seizure reduction. On the other hand, only three patients reported side effects related to clobazam, which was disturbing enough to discontinue the medication in only one, although clobazam was added as a third or more AEDs in all of the patients.

Clobazam is a 1-5 benzodiazepine, which was first synthesized as an anxiolytic drug; however, after the recognition of its efficacy over epileptic seizures in the late 1970s by Gastaut et al. ${ }^{[4]}$ it has been used in PWE, especially in case of drug-resistant epilepsy. ${ }^{[6-8,11]}$ Later, the anxiolytic effect of clobazam was considered as low compared to 1-4 benzodiazepines, limiting its utility in psychiatry. ${ }^{[18]}$ In addition, its sedative effect was reported to be less considerable than the other benzodiazepines. ${ }^{[15]}$

Anticonvulsant activity of clobazam was related to GABAA receptor $a$ - and $\Upsilon^{2}$-subunit. ${ }^{[15-17]}$ The allosteric binding to GABAA receptor enhances the inhibitory effect of GABA by increasing the frequency of opening state of the $\mathrm{Cl}$ - channel. [15] Additionally, it upregulates GABA transporter proteins. [13] The low affinity of a-subunit is responsible for a reduced sedation effect. ${ }^{[18,20]}$ Oral bioavailability is high, reaching a plasma peak concentration within 1-3 hours after administration. ${ }^{[17,23]}$ It has active metabolites that are produced in the liver by oxidation. ${ }^{[15]}$ Clobazam is eliminated in urine. ${ }^{[19,23]}$ The starting dose should be 5-10 mg per day, and the dose can be increased weekly to a maximum dose of 30-40 mg per day. Although daily once dosing is suitable related to long half-lime, doses exceeding $10 \mathrm{mg}$ per day is recommended to be administered twice a day to avoid side effects. ${ }^{[17]}$

The efficacy of clobazam is widely studied, including randomized controlled studies. ${ }^{[5,6,8-10,14]}$ As an adjunctive treatment, clobazam was reported to achieve $\geq 50 \%$ seizure reduction in $\geq 50$ of the patients and seizure freedom in more than $10 \%$ of the patients with Lennox-Gastaut Syndrome. $[5,9-11,17]$ Our result showed similar efficacy of clobazam with those of the previous studies as an adjunctive treatment. Most of our patients had focal onset seizures. Clobazam is considered to be effective for both focal and generalize seizure subtypes. However, there were some reports suggesting that it may be more efficacious in focal onset seizures than generalized onset seizures. ${ }^{[9,10]}$ In Lennox-Gastaut Syndrome, clobazam was reported to be more effective for atonic and myoclonic seizures and drop attacks. ${ }^{[11,17]}$ As a monotherapy, clobazam was studied in Rolandic epilepsy and focal epilepsy in children. These studies indicated a similar efficacy of clobazam when compared to carbamazepine and phenytoin. ${ }^{[24-26]}$

Clobazam may increase the plasma concentration of valproate. ${ }^{[17,23]}$ In our study, there were only two patients taking valproate. One of them reported sedation as a side effect, which was not severe to discontinue the medication. This patient did not show benefit from the drug. The second case reported no side effects and achieved $\geq 50 \%$ seizure reduction. In addition, all of our patients had two or more AEDs with moderate to high doses. Clobazam as add-on therapy did not show disturbing side effects except in one patient who discontinued the drug in the early phase. Future studies may unravel the drug to drug interactions between clobazam and different AEDs.

\section{Study limitation}

The main limitation of our study was its retrospective design. The seizure reduction and side effects were collected through patients' charts that were meticulously recorded by epilepsy experts.

\section{Conclusion}

Clobazam is seemed to be efficacious in drug-resistant PWE as an add-on therapy hosting a possibility of seizure freedom without serious side effects.

\section{Acknowledgment}

The authors thank Ender Bostancı and Hakan Yener for their help in collecting the data from archives.

\section{Ethics Committee Approval}

Ethics committee approved.

\section{Peer-review}

Externally peer-reviewed. 


\section{Conflict of interest}

The authors declare that they have no conflict of interest.

\section{Authorship Contributions}

Concept: N.G.Ş., N.B.; Design: N.G.Ş., N.B.; Supervision: N.G.Ş., B.B., N.B.; Data collection \&/or processing: N.G.Ş.; Analysis and/or interpretation: N.G.Ş., B.B., N.B.; Literature search: N.G.Ş.; Writing: N.G.Ş.; Critical review: B.B., N.B.

\section{References}

1. Scheffer IE, Berkovic S, Capovilla G, Connolly MB, French J, Guilhoto L, Hirsch E, Jain S, Mathern GW, Moshé SL, Nordli DR, Perucca E, Tomson T, Wiebe S, Zhang YH, Zuberi SM. ILAE classification of the epilepsies: Position paper of the ILAE Commission for Classification and Terminology. Epilepsia 2017;58(4):512-21. [CrossRef]

2. Cockerell OC, Johnson AL, Sander JW, Hart YM, Shorvon SD. Remission of epilepsy: results from the National General Practice Study of Epilepsy. Lancet 1995;346(8968):140-4. [CrossRef]

3. Odom N, Bateman LM. Sudden unexpected death in epilepsy, periictal physiology, and the SUDEP-7 Inventory. Epilepsia 2018;59(10):e157-e160. [CrossRef]

4. Gastaut H, Low MD. Antiepileptic properties of clobazam, a 1-5 benzodiazepine, in man. Epilepsia 1979;20(4):437-46. [CrossRef]

5. Allen JW, Oxley J, Robertson MM, Trimble MR, Richens A, Jawad SS. Clobazam as adjunctive treatment in refractory epilepsy. $\mathrm{Br}$ Med J (Clin Res Ed) 1983;286(6373):1246-7. [CrossRef]

6. Arya R, Giridharan N, Anand V, Garg SK. Clobazam monotherapy for focal or generalized seizures. Cochrane Database Syst Rev 2018;7(7):CD009258. [CrossRef]

7. Arya R, Anand V, Garg SK, Michael BD. Clobazam monotherapy for partial-onset or generalized-onset seizures. Cochrane Database Syst Rev 2014;(10):CD009258. [CrossRef]

8. Bresnahan R, Martin-McGill KJ, Williamson J, Michael BD, Marson AG. Clobazam add-on therapy for drug-resistant epilepsy. Cochrane Database Syst Rev 2019;10(10):CD004154. [CrossRef]

9. Keene DL, Whiting S, Humphreys P. Clobazam as an add-on drug in the treatment of refractory epilepsy of childhood. Can J Neurol Sci 1990;17(3):317-9. [CrossRef]

10. Schmidt $D$, Rohde $M$, Wolf $P$, Roeder-Wanner U. Clobazam for refractory focal epilepsy. A controlled trial. Arch Neurol 1986;43(8):824-6. [CrossRef]

11. Conry JA, Ng YT, Paolicchi JM, Kernitsky L, Mitchell WG, Ritter FJ, et al. Clobazam in the treatment of Lennox-Gastaut syndrome. Epilepsia 2009;50(5):1158-66. [CrossRef]
12. Mehndiratta MM, Krishnamurthy $M$, Rajesh KN, Singh G. Clobazam monotherapy in drug naïve adult patients with epilepsy. Seizure 2003;12(4):226-8. [CrossRef]

13. Jennesson M, van Eeghen AM, Caruso PA, Paolini JL, Thiele EA. Clobazam therapy of refractory epilepsy in tuberous sclerosis complex. Epilepsy Res 2013;104(3):269-74. [CrossRef]

14. Koeppen D, Baruzzi A, Capozza M, Chauvel P, Courjon J, Favel $P$, et al. Clobazam in therapy-resistant patients with partial epilepsy: a double-blind placebo-controlled crossover study. Epilepsia 1987;28(5):495-506. [CrossRef]

15. Möhler H, Fritschy JM, Rudolph U. A new benzodiazepine pharmacology. J Pharmacol Exp Ther 2002;300(1):2-8. [CrossRef]

16. Hanks GW. Clobazam: pharmacological and therapeutic profile. Br J Clin Pharmacol 1979;7(Suppl 1):151S-155S. [CrossRef]

17. Giarratano M, Standley K, Benbadis SR. Clobazam for treatment of epilepsy. Expert Opin Pharmacother 2012;13(2):227-33.

18. Fielding S, Hoffmann I. Pharmacology of anti-anxiety drugs with special reference to clobazam. Br J Clin Pharmacol 1979;7(Suppl 1):7S-15S. [CrossRef]

19. Ng YT, Collins SD. Clobazam. Neurotherapeutics 2007;4(1):13844. [CrossRef]

20. Singh A, Guberman AH, Boisvert D. Clobazam in long-term epilepsy treatment: sustained responders versus those developing tolerance. Epilepsia 1995;36(8):798-803. [CrossRef]

21. Ekici A, Ozdemir O, Yimenicioglu S, Oren A, Sen I. Hot Water Epilepsy Successfully Treated With Daily Clobazam. Pediatr Emerg Care 2017;33(10):e98-e99. [CrossRef]

22. Kwan P, Arzimanoglou A, Berg AT, Brodie MJ, Allen Hauser W, Mathern $G$, et al. Definition of drug resistant epilepsy: consensus proposal by the ad hoc Task Force of the ILAE Commission on Therapeutic Strategies. Epilepsia 2010;51(6):1069-77.

23. Abou-Khalil BW. Antiepileptic Drugs. Continuum (Minneap Minn) 2016;22(1 Epilepsy):132-56. [CrossRef]

24. Kaushal S, Rani A, Chopra SC, Singh G. Safety and efficacy of clobazam versus phenytoin-sodium in the antiepileptic drug treatment of solitary cysticercus granulomas. Neurol India 2006;54(2):157-60.

25. AndradeR, García-Espinosa A, Machado-Rojas A, García-González ME, Trápaga-Quincoses $\mathrm{O}$, Morales-Chacón LM. A prospective, open, controlled and randomised study of clobazam versus carbamazepine in patients with frequent episodes of Rolandic epilepsy. Rev Neurol 2009;49(11):581-6. [CrossRef]

26. Clobazam has equivalent efficacy to carbamazepine and phenytoin as monotherapy for childhood epilepsy. Canadian Study Group for Childhood Epilepsy. Epilepsia 1998;39(9):952-9. 